\title{
Response to the letter to the editor entitled "Regarding long-term lead elimination from plasma and whole blood after poisoning"
}

\author{
G. Rentschler $\cdot$ K. Broberg $\cdot$ T. Lundh $\cdot$ S. Skerfving
}

Received: 18 August 2011 / Accepted: 19 August 2011 / Published online: 1 September 2011

(C) The Author(s) 2011. This article is published with open access at Springerlink.com

\section{Dear Sir,}

In relation to our paper on plasma lead in poisoned subjects (Rentschler et al. 2011), professor Sanaei-Zadeh asks for additional information on three aspects: (1) laboratory status regarding kidneys, liver, and bone marrow (2) our definition of "severe poisoning", and (3) treatment.

Ad (1): All five cases had serum creatinine concentrations within the reference limits of our laboratory. Determination of blood urea nitrogen is not a clinical routine in our department. As regards serum transferases, case No. 3 had a slight, transient rise initially [aspartate aminotransferase: 0.88 (upper reference limit 0.60$) \mu \mathrm{kat} / \mathrm{L}$; alanine aminotransferase: $1.1(0.75) \mu \mathrm{kat} / \mathrm{L})]$, while all the others were "normal". Cases No. 1, 3, and 5 had typical microcytic sideroblastic anemia in bone marrow biopsies. Only case No. 5 was examined for basophilic stippling of erythrocytes in peripheral blood; he displayed such.

Ad (2): We agree that our use of "severe" in some of the present cases may not be fully justified, and "moderate" may perhaps be more adequate for cases No. 1-4, while No. 5 is "severe". What we wanted to emphasize by using the term severe is that we were not discussing the kind of subclinical lead toxicity, which has been a major concern during the last decades (Skerfving and Bergdahl 2007).

Ad (3): For several reasons, we did not administer chelating agents to the patients. All cases (even No. 5, who was exposed in an occupational setting) had large amounts of

G. Rentschler $(\bowtie) \cdot$ K. Broberg $\cdot$ T. Lundh $\cdot$ S. Skerfving Division of Occupational and Environmental Medicine, Lund University, 22185 Lund, Sweden

e-mail: Gerda.Rentschler@med.lu.se lead in their gastrointestinal tracts. Since oral chelation therapy may increase the absorption of lead (Skerfving and Bergdahl 2007), we avoided such. Moreover, the symptoms and signs did not warrant intravenous therapy, in particular, since the effect of such on bioavailable lead is very temporary in subjects with a large bone-lead pool, which rapidly reconstitutes lead in target organs by endogenous exposure. Also, the clinical status improved significantly soon after the source of lead exposure had been located and the lead intake was stopped.

At last, one more thing: Professor Sanaei-Zadeh mentions a whole-blood-lead level of $100 \mu \mathrm{g} / \mathrm{dL}$ as typical for severe lead poisoning. That touches upon one of the main messages of our paper: Whole-blood lead at that level is uninformative and may be very misleading, since there is saturation. Caregivers may have a tendency to interpret the level as rectilinearly related to exposure and tissue levels which it is not. Hence, $100 \mu \mathrm{g} / \mathrm{dL}$ may indicate either a high or an extremely high exposure. Our data show that plasma lead is much more informative at heavy exposure, since it is rectilinearly related to exposure and tissue levels, and is a valuable tool.

Open Access This article is distributed under the terms of the Creative Commons Attribution Noncommercial License which permits any noncommercial use, distribution, and reproduction in any medium, provided the original author(s) and source are credited.

\section{References}

Rentschler G, Broberg K, Lundh T, Skerfving S (2011) Long-term lead elimination from plasma and whole blood after poisoning. Int Arch Occup Environ Health. doi:10.1007/s00420-011-0673-0

Skerfving S, Bergdahl IA (2007) Lead. In: Nordberg GF, Fowler BA, Nordberg M, Friberg LT (eds) Handbook on the toxicology of metals, 3rd edn. Academic Press, New York, pp 599-643 